
ЗАКОНОМІРНОСТІ РОЗВИТКУ САМОСТІЙНОЇ ДІЯЛЬНОСТІ СТУДЕНТІВ
НАПРИКІНЦІ ХХ - НА ПОЧАТКУ ХХІ СТ.

\title{
REGULARITIES OF DEVELOPMENT OF STUDENTS' INDIVIDUAL WORK AT THE END OF THE XXTH - THE BEGINNING OF THE XXIST CENTURY
}

\begin{abstract}
Процес фрормування особистості студента має иілісний характер. У цьому контексті надзвичайно важливий виховний потенціал самостійної діяльності студента. В історичному плані зазначеному питанню практично не надавали значення, хоча деякі аспекти (наприклад, розвиток самостійності мислення) розглядали. У досліджуваний період відбулася ґрунтовна переоцінка матеріалу для самостійної діяльності студентів, особливо в галузі суспільних наук, а також спостерігаються позитивні зміни від одноманітності продукту самостійної діяльності (реферат, доповідь) до значного розширення форм (есе, кейс, проект, презентація тощо). Попри це, недостатньо уваги приділено врахуванню особливостей майбутньої професійної діяльності студента в контексті орорм і методів такої діяльності. Виявлена також тенденція зближення видів самостійної діяльності студентів і учнів, що відповідає принципу неперервності освіти. Визначено закономірності самостійної роботи студентів, які сорормувалися у досліджуваний період. Першою закономірністю $є$ вплив рівня ссрормованості самостійної діяльності учня на чей самий рівень, коли учень стає студентом. Другою закономірністю вважаємо взаємодію емпіричного й теоретичного, що є джерелом розвитку самостійно роботи студента. Третя закономірність передбачає появу чілковито нових джерел добування інформації для самостійноі діяльності (інформаційно-комунікаційних технологій). $у$ досліджуваний період це співвідношення постійно змінювалося. Критичним моментом було активне застосування комп'ютерів у навчальному прочесі та якісно нові способи самостійної діяльності студентів, зумовлені цими змінами. Четверта закономірність передбачає необхідність акцентування у самостійній роботі студентів не так на накопиченні й пошуку інформації, як на фрормуванні навичок роботи з чією інформацією, перетворенні їі на власні знання, виробленні необхідних умінь. Згідно з п'ятою закономірністю розвиток самостійної діяльності студента має супроводжуватися інтеграцією та диференціацією їі змісту, форм, методів і засобів реалізації. Історія самостійної діяльності свідчить, що процеси дифреренціації й інтеграції не витісняють один одного, а взаємно переплітаються й переходять один в одного.
\end{abstract}

канд. пед. наук

доцент кафедри практичної психологі та педагогіки

Львівського державного університету

безпеки життєдіяльності
Ключові слова: самостійна діяльність, навчальний процес, виховний потенціал, закономірності, розвиток, кінець XX - початок XXI cm.

The student's personality formation process is holistic in nature. In this context the training aspect of student's individual work is extremely important. In the historical context this issue has been hardly referred to, although some aspects (such as the development of individual thinking) have been considered. A thorough reassessment of material for students' individual work, especially in social sciences, has taken place, and positive hanges from a product monotony of individual work (abstract, report) to a significant expansion in forms (essay, case, project, presentation, etc.) have been observed. However, little attention is still paid to considering the features of a student's future professional activity in the context of forms and methods of individual work. The convergence tendency of students and pupils' individual work activity types has been found, which corresponds to the principle of continuity of education. The regularities of student's individual work, formed during the studied period, have been determined. The first regularity is the influence of a level of pupil's individual work on this very level when a pupilbecomes a student. The second regularity is the interaction of the empirical and theoretical, which is a source of development of student's individual work. The third regularity implies the emergence of completely new sources of obtaining information for individual work (information and communication technologies). In the studied period, this ratio was being constantly changed. The critical point was the universal introduction of computers into the educational process and qualitatively new ways of student's individual work generated by these changes. The fourth regularity means the need to emphasize not only the accumulation and search of information in student's individual work but the formation of skills to work with this information, transformit in to one's own knowledge and form necessary skills. The fifth regularity claims that the development of student's individual work should be accompanied by the integration and differentiation of its content, forms, methods and means of implementation. The history of individual work shows that the processes of differentiation and integration do not displace each other but intersect.

Key words: individual work, educational process, training aspect, regularities, development, end of the XXth - the beginning of the XXIst century.
Постановка проблеми у загальному вигляді. Процес формування особистості студента цілісний, і тут украй важливі дидактичний і виховний потенціали самостійної діяльності студента. Упродовж XX - XXI ст. відбулася ґрунтовна переоцінка матеріалу для самостійної діяльності студентів, особливо в галузі суспільних наук, а також спостерігаються позитивні зміни від одноманітності про- дукту самостійної діяльності (реферат, доповідь) до значного розширення фрорм (есе, кейс, проект, презентація тощо). Виявлено також тенденцію зближення видів самостійної діяльності студентів і учнів, щовідповідаєпринципунеперервностіосвіти.

Відповідно до історичного досвіду самостійна діяльність студентів у становленні й розвитку проходить дві стадії: стадію накопичення емпіричного 
матеріалу і стадію його теоретичної обробки, тож першочергове значення в ії розвитку посідає діалектичне співвідношення емпірики та теорії.

Аналіз останніх досліджень і публікацій. У класичних працях із дидактики (Я. Коменський, Е. Мейман, Е. Торндайк, М. Скаткин, І. Лернер та ін.) розглянуто закономірності, конкретизація яких безпосереньо стосується самостійної діяльності студента, наприклад: усе, що підлягає вивченню, нехай спершу пропонується в загальному вигляді, а потім по частинах; розвиток індивіда 3 самого початку визначається здебільшого природними задатками; коли процес встановлення зв'язку між ситуацією і реакцією у відповідь супроводжується або змінюється станом задоволення, а зв'язок зростає.

У другій половині XX ст. інтерес до теоретизації основ самостійної діяльності студента переходить у стійку тенденцію, до нього звертаються провідні вчені (В. Беспалько [2], Ю. Бабанський [1] та ін.). Особливу увагу закономірностям навчального процесу приділяв I. Підласий [5], який вивів низку таких закономірностей: ефективність навчання визначається способами структурування змісту освіти; особистісне пізнання фундаментальних освітніх об'єктів закономірно приводить до побудови особистісної системи знань, адекватної дійсності, що вивчається, і освітніх стандартів; освітні результати залежать не від обсягу матеріалу, що вивчається, а від змісту освітньої продукції тощо. На думку І. Козловської, «важливим для сучасної освіти $€$ пошук фрундаментальних знань і цінностей, які би могли сформувати відповідні педагогічні системи, що базуються на небагатьох закономірностях, яким підпорядковуються всі інші. Розробки у дидактиці, пов'язані з розвитком статистичних уявлень чи принципом невизначеності, не дадуть позитивних результатів доти, поки не будуть розроблені теоретичні основи класичної, лінійної дидактики» [3, с. 350].

На теоретичному і методологічному рівнях проблему організації самостійної діяльності студентів розглядали М. Данилов, Б. Єсіпов, Г. щукіна, М. Солдатенко, І. Гриценко, О. Падерін, Є. Танько, А. Бучинський, О. Бондаровська, В. Бенера, О. Малихін та ін.

Виділення не вирішених раніше частин загальної проблеми. Попри зазначене, врахуванню закономірностей і розвитку теорії самостійної діяльності студента приділено недостатньо уваги. Накопичений досвід самостійної діяльності - як матеріал для виведення та виявлення її закономірностей - на наш погляд, сягає часів перших дослідницьких університетів і налічує багато століть. Для становлення теорії самостійної діяльності необхідне виявлення її закономірностей і відкриття законів, що і становить сутність наукової теорії.
Мета статті - проаналізувати педагогічні закономірності та виявити закономірності розвитку самостійної діяльності студентів наприкінці XX - на початку XXI ст.

Виклад основного матеріалу. Досліджуючи процес самостійної діяльності студентів, вважаємо за необхідне узагальнити деякі педагогічні закономірності у контексті розвитку самостійної діяльності студента в досліджуваний період.

Дослідження балансу між загальним і конкретним у самостійній діяльності належить до важливих закономірностей у подальшій побудові концепцій цієї діяльності. Ланцюжок неперервної діяльності, яку має виконати студент для засвоєння певної частини навчального матеріалу, має бути науково обґрунтованим і оптимізованим. Якщо буде забагато загального, затеоретизовані знання не дадуть змоги студентові здійснювати повноцінну самостійну діяльність, а брак теоретичної інсормації також ускладнюватиме роботу. Зауважимо, що в різні епохи погляди на це співвідношення були різними, іноді діаметрально. Наприкінці XX - на початку XXI ст. з укоріненням модульної системи навчання організація змісту самостійної діяльності змінювалася згідно з філософськими категоріями загального і конкретного. Така динаміка, на наш погляд, позитивна.

Необхідність урахування індивідуальних рис студента за досліджуваний період пройшла шлях від малозначущої до провідної закономірності, й така тенденція зростає. Розуміння цього закону навіть зараз недостатньо глибоке. Вважаємо, що проблема фуннцій самостійної діяльності у навчанні студентадосліджена недостатньо: завжди визначали ії важливі роль, види, форми, однак чіткого розуміння і рангування фуннкцій немає досі.

Закономірний зв'язок між вимогами до самостійної діяльності в ЗВО та наявним досвідом цієї діяльності в кожного студента - важлива ланка для побудови теорії самостійної діяльності. На межі століть відчувається певне зростання інтересу до наступності самостійної діяльності. Виокремимо тут принаймні два напрями дослідження: загальні питання наступності у самостійній діяльності студента за переходу зі школи у ЗВО та індивідуальний досвід студента. Вважаємо, що, можливо, доцільними будуть певна класифрікація і групування студентів за їх досвідом самостійної діяльності на початку навчання у ЗВО. Водночас задоволення й очевидні результати самостійної діяльності є потужним мотиваційним чинником.

Проблема браку часу на самостійну діяльність - одна з ключових. Ще із середини минулого століття намагалися відшукати закономірності між часом, якістю й обсягом самостійної діяльності студента. Знову ж відзначимо певні якісні зміни стосовно кредитно-модульної системи, яка 
утвердилася в Україні наприкінці минулого століття. На наш погляд, роль самостійної діяльності тут винятково важлива - створення відповідного освітнього середовища, де така діяльність $€$ повноцінним компонентом. Розподіл навчального матеріалу між аудиторними заняттями та винесенням на самостійну діяльність був і залишається провідним у теорії самостійної роботи. Тут необхідне залучення основ усіх педагогічних, спеціальних наук, психології.

Процес формування особистості студента має цілісний характер, тобто всі фуннції, властивості та якості людини розвиваються комплексно, утворюючи цілісну систему. У цьому контексті надзвичайно важливий виховний потенціал самостійної роботи студента. В історичному контексті цьому питанню практично не надавали значення, хоча деякі аспекти (наприклад, розвиток самостійності мислення) таки розглядали. Однак власне виховна роль самостійної роботи протягом досліджуваного періоду (і до цього) залишалася на периферії досліджень самостійної діяльності студентів.

На наш погляд, незначні тенденції посилення цього аспекту самостійної діяльності з'явилися останніми роками: для їх аналізу необхідно проаналізувати сутність та еволюцію основних закономірностей і принципів виховання у контексті самостійної роботи студентів. Зміна державного устрою України, пов'язана 3 розпадом СРСР, суттєво вплинула на зміст виховного процесу, зокрема у ЗВО. Упродовж досліджуваного періоду відбулася ґрунтовна переоцінка матеріалу для самостійної роботи студентів, особливо в суспільних науках. Хоча і для студентів технічних спеціальностей, які були змушені в радянські часи конспектувати оригінали праць Леніна, Маркса, матеріали з'їздів КПРС і ще багато такого трибу джерел, зміни були дуже вагомі. Адже у процесі конспектування першоджерел фрормуються багато навичок і ставлення до самостійної навчальної діяльності.

Водночас саме у досліджуваний період відбулися позитивні зміни від одноманітності продукту самостійної діяльності студента (реферат, доповідь) до значного розширення фрорм (есе, кейс тощо) та засобів (презентація). Революційний вплив інфрормаційно-комунікаційних технологій і самостійної діяльності студента - питання, що вимагає окремого дослідження.

Отже, виокремимо закономірності розвитку самостійної діяльності студента наприкінці XX - на початку XXI cm.

Теорія самостійної діяльності студентів тісно пов'язана з результатами самостійної діяльності учнів. Тому перша закономірність - вплив рівня сорормованості самостійної діяльності (самостійно сфрормованих знань та умінь, а також здатності самостійно набувати знання та вміння) учня на той самий рівень, коли учень стає студентом. Аналіз теоретичних концепцій самостійної роботи учнів і студентів упродовж кінця XX - початку XXI ст. показує, що власне ця закономірність зазнала істотної трансорормації. 3 одного боку, домашні завдання як вид самостійної роботи учня мали б підготувати його до аналогічної діяльності у 3ВО. 3 іншого - відчувалася якісна відмінність між видами самостійної діяльності у школі та ЗВО. Передусім це стосувалося обсягів навчального матеріалу та видів самостійної діяльності. У досліджуваний період види діяльності учнів і студентів стали близькими - розглядаємо це як позитивну тенденцію зближення видів самостійної діяльності студентів і учнів, що зросла і зростає далі.

В основу самостійної роботи покладено два протилежні наукові методи: індуктивно-емпіричний і дедуктивно-теоретичний. Водночас були історичні періоди, коли на перше місце в дослідницькій діяльності виходив емпіризм (наприклад, на початковому етапі становлення окремих наук, коли провідними були опис і збір фрактів) або раціоналізм, породжений необхідністю систематизації й теоретичного аналізу зібраних емпіричних знань. Тому другою закономірністю вважаємо взаємодію емпіричного $і$ теоретичного, що $\epsilon$ джерелом розвитку самостійної діяльності. У самостійній роботі студента не завжди маємо оптимальне співвідношення теоретичного й емпіричного, раціонального і чуттєвого компонентів діяльності. Теоретичні й емпіричні результати самостійної діяльності (як і їх планування та передбачення) необхідно розглядати в нерозривній єдності, яка забезпечує цілісність розвитку самостійної діяльності.

Критичним моментом було активне введення інформаційно-комунікативних технологій у навчальний процес і якісно нові способи самостійної діяльності студентів, зумовлені цими змінами. Відтак виникла третя закономірність, яка передбачає появу чілковито нових джерел добування інформації для самостійної діяльності. Протягом досліджуваного періоду розвитку самостійної діяльності діалектичне співвідношення традицій і новацій суттєво змінилося. Якщо у 80-х рр. інноваційні засоби та методи навчання лише частково впливали на сутність самостійної діяльності, то 3 початку XXI ст. стрімко зріс їх вплив. Це пов'язано 3 тим, що власне в царині самостійної діяльності суттєву роль відіграють пошук і зберігання інфрормації, її копіювання, перетворення.

Потужні можливості Інтернету, з одного боку, істотно спростили пошук інфрормації, а 3 іншого з'явилися негативні тенденції: наприклад, спрощений вихід на джерела і легке користування ними створили шкідливу ілюзію простоти й доступності в навчальній самостійній діяльності. Тому вважа- 
ємо, що дуже важливим завданням у розробці майбутніх і розвитку сучасних теорій самостійної діяльності $€$ те, що утворює четверту закономірність - необхідність акцентування у самостійній діяльності не так на накопиченні та пошуку самостійно інформації, як на фрормуванні навичок роботи з чією інфрормацією, перетворенні їі на власні знання, виробленні необхідних умінь.

В основу поняття «традиційне знання» покладено одну 3 найважливіших особливостей розвитку: через них забезпечується спадкоємність між поколіннями людей і зберігаються досягнення кожного з них. Під поняттям нового знання у філоcoфії самостійної діяльності розуміють «будь-який дискретний елемент знання, що збагачує (розширює або поглиблює) систему знань про світ і задовольняє вимоги нетривіальності та самостійної раціональності» [6, с. 50].

Поряд із традиціями і новаціями кожна конкретна самостійна діяльність, кожен навчальний заклад чи навіть окремий студент створюють власні шляхи цієї діяльності. Поява нового можлива тільки через подолання традицій, але подолання розумного, на основі закону заперечення заперечення, тобто щоразу надаючи можливість позитивним традиціям відродитися в новому середовищі, за нових умов, на новій теоретико-методологічній основі чи в рамках нової парадигми освіти.

Методологічне і практичне значення закону заперечення заперечення важливе для розуміння наступності зв'язку. Якщо нове виникає зі старого, то в галузі самостійної діяльності потрібно вміти віддати належне досягненням минулого, критично сприйняти його найвагоміші результати. Наступність «відіграє особливо важливу роль у науці й техніці: не знаючи їх історії, не знаючи, ким, в якій обстановці зароджувалися і здійснювалися ті або інші ідеї і творчість, немислиме правильне розуміння розвитку культури, а тому немислима i правильна оцінка сучасних досягнень, немислиме передбачення найближчих перспектив» [4, с. 62] Однак наступність розвитку - не те саме, що його неперервність: в історії самостійної діяльності були періоди неперервного розвитку за сталими принципами, але ці періоди неминуче змінювалися періодами заперечення, стрибками в розвитку. Наступність, з одного боку, є основою розвитку, що йде від одного рівня до іншого, а з іншого - необхідна умова будь-якої форми змін.

5. У сучасних умовах дедалі істотнішим аспектом освіти $€$ інтеграційні тенденції. Звідси виводимо п'яту закономірність - розвиток самостійноі діяльності має супроводжуватися інтеграцією й дифреренціацією їі змісту, фрорм, методів і засобів реалізації. Історія самостійної діяльності свідчить, що процеси диференціації й інтеграції не витіс- няють один одного, а взаємно переплітаються і переходять один в одного. Під єдністю самостійної діяльності мається на увазі результат дії інтегративних тенденцій, внутрішній стан самостійної діяльності, її структура як цілісного організму. Водночас єдність самостійної діяльності, її цілісність та органічний взаємозв'язок усіх її галузей - це історичний продукт, підсумок тривалого, суперечливого і нескінченного шляху теоретичного освоєння дійсності.

Висновки. У досліджуваний період відбулася ґрунтовна переоцінка матеріалу для самостійної діяльності студентів, особливо в галузі суспільних наук, а також спостерігаються позитивні зміни від одноманітності продукту самостійної діяльності до значного розширення форм. Визначено закономірності самостійної діяльності студентів, які сорормувалися у досліджуваний період: вплив рівня сорормованості самостійної діяльності учня на той самий рівень, коли учень стає студентом; взаємодія емпіричного й теоретичного, що є джерелом розвитку самостійної діяльності студента; поява цілковито нових джерел добування інформації для самостійної діяльності (інформаційно-комунікаційних технологій, впровадження комп'ютерів у навчальний процес і якісно нових способів самостійної діяльності студентів, зумовлених цими змінами); необхідність акцентування у самостійній діяльності студентів не так на накопиченні та пошуку інфрормації, якна фрормуванні вмінь роботи з цією інформацією, перетворенні її на власні знання, виробленні необхідних умінь; розвиток самостійної діяльності студента має супроводжуватися інтеграцією й дифреренціацією іiї змісту, фрорм, методів і засобів реалізації.

\section{БІБЛІОГРАФІЧНИЙ СПИСОК:}

1. Бабанский Ю.К. Оптимизация процесса обучения: (Общедидактический аспект). Москва : Педагогика, 1977. 190 с.

2. Беспалько В.П. Педагогика и прогрессивные технологии обучения. Москва : Педагогика, 1995. $208 \mathrm{c}$.

3. Козловська І.М. Закони і закономірності дидактики. Розвиток педагогічної та психологічної наук в Україні 1992-2002 : збірник наукових праць до 10-річчя АПН України / Академія педагогічних наук України. Ч. 2. Харків : ОВС, 2002. С. 348-358.

4. Орлов В.Ф. Методологічні засади професійного становлення фрахівця. Неперервна профресійна освіта: теорія і практика. Київ : НТУ «ХП|», 2001. ч. 1. С. 60-67.

5. Підласий І.П. Практична педагогіка або три технології: інтерактивний підручник для педагогів ринкової системи освіти. Київ : Видавничий Дім «Слово», 2004. 616 с.

6. Славин А.В. Проблема возникновения нового знания. Москва : Наука, 1976. 295 с. 